\title{
The effect of diurnal variation on total plasma calcium concentration in normal subjects
}

M. R. WILLS ${ }^{1}$

From the Department of Chemical Pathology, Bristol Royal Infirmary, Bristol

SYNOPSIS In 12 normal subjects plasma calcium and phosphorus concentrations were estimated during a normal working day. In the individual subjects fluctuations from the fasting values occurred during the period of study, but at no time during that period did the mean values differ significantly from the fasting plasma calcium or phosphorus concentrations. In three of the subjects the study was repeated while fasting durins a normal working day. In these subjects the fluctuations in both plasma calcium and phosphorus concentrations were less than during a normal day while taking meals, and there was evidence of a diurnal variation in the plasma phosphorus concentration.

The alternation of daily activity and nocturnal sleep is associated with a circadian rhythm in the concentration of some blood constituents and in the renal output of water and electrolytes (Mills, 1966). Studies of circadian variation in total plasma calcium concentration are conflicting. In fasting subjects some have reported that no fluctuations occur (Greenberg and Gunther, 1930 and 1932; Philpot, 1958), while others have reported changes of 2 or $3 \mathrm{mg}$ per $100 \mathrm{ml}$ during a 24-hour period (Nicolaysen, 1932). Similarly in subjects on a normal diet it has been reported that there are no appreciable variations (Watchorn, 1929; Carruthers, Copp, and McIntosh, 1964), while others have reported marked fluctuations (Philpot, 1958; Chaptal, Jean, Guillamot, and Morel, 1962). Farquharson and Tibbetts (1931), in a study of two healthy adults during ordinary work, found that the plasma calcium concentration was constant in one and varied in the other. In view of these conflicting reports, and as the estimation of total plasma calcium concentration is, at present, one of the most valuable indices of disorders of calcium homeostasis, the study reported here was undertaken in an attempt to define the effect of diurnal variation on total plasma calcium concentration in normal subjects.

Received for publication 4 May 1970.

\section{Subjects Studied}

Nine males and three females were studied. All were healthy members of the laboratory staff and their ages ranged from 22 to 50 years. During the day of study they followed their normal daily work routine and received a standard diet. The diet was prepared to give a normal content of fat, carbohydrate, and protein with a fixed calcium intake of $1,100 \mathrm{mg} / \mathrm{day}$; this approximately equalled their usual diet and the normal daily adult intake (National Food Survey, 1963). The distribution of the calcium intake (mainly as milk) through the study day was $260 \mathrm{mg}$ at $0915,140 \mathrm{mg}$ at $1030,245 \mathrm{mg}$ at $1230,220 \mathrm{mg}$ at 1530 , and $235 \mathrm{mg}$ at 1830 hours.

\section{Routine of Specimen Collection}

After an overnight fast blood was collected at 0900 hours and thereafter at approximately three-hourly intervals with a final blood specimen at $\mathbf{2 0 0 0}$ hours in nine of the subjects. In the other three subjects blood specimens were col-

'Present address: Department of Chemical Pathology, Royal Free Hospital, Lawn Road, London, NW3. 
lected at 1030 and 1300 hours and thereafter at the same time as in the other subjects. The timing of the blood specimens in relation to meals (which were taken at $0915,1030,1230,1530$, and 1830 hours) was such as to provide specimens at varying intervals after meals.

Blood samples were collected, venous and without stasis, into heparin containers (sodium heparin 10 units per $\mathrm{ml}$ ).

\section{Methods}

Plasma calcium concentration was estimated by the plasma-Corinth B (Corinth calcium) AutoAnalyzer method of Wills and Gray (1964). The standard deviation of replicate estimations was $\pm 0.05 \mathrm{mg}$ per $100 \mathrm{ml}$. The specific gravity of the plasma samples was estimated by the copper sulphate drop method of Phillips, van Slyke, Dole, Emerson, Hamilton, and Archibald
(1945). The estimated plasma calcium values werecorrected to a standard specific gravity of 1.027.0 as proposed by Dent (1962).

Plasma phosphorus concentration was estiô․ mated by the method of Fiske and Subbarov (1925).

\section{Results}

The full results for the 12 subjects studied aro detailed in Table I, together with the values for the mean and standard deviation (SD) at the $\vec{\omega}$ times studied. The results through the day have also been compared by Student's $t$ index with? the fasting calcium and phosphorus concentra tions, and the $P$ values determined. At no timee during the day of study did the mean values for plasma calcium or phosphorus differ significantly from the fasting levels. In only two subjects (nos. 2 and 9) were the fasting plasma calcium


Fig. 1 Changes in plasma calcium concentration, in 12 normal subjects, during a normal working day plotted as the difference in $\mathrm{mg}$ per $100 \mathrm{ml}$ from the 0900 hour fasting concentration - . The mean difference from the fasting concentration at each time is also plotted (-). The dietary calcium intake in $\mathrm{mg}$ (black areas) and times taken are also shown. 
Subject Sex Age Time (hours)

$M e a n \pm S D$

\begin{tabular}{llllllllllllll}
\hline $0900^{2}$ & 1030 & & 1200 & & 1300 & & 1500 & & 1800 & & 2000 & \\
\hline $\mathrm{Ca}^{2}$ & $P^{2}$ & $\mathrm{Ca}$ & $P$ & $\mathrm{Ca}$ & $\boldsymbol{P}$ & $\mathrm{Ca}$ & $\boldsymbol{P}$ & $\mathrm{Ca}$ & $\boldsymbol{P}$ & $\mathrm{Ca}$ & $\boldsymbol{P}$ & $\mathrm{Ca}$ & $\boldsymbol{P}$
\end{tabular}

$\mathrm{Ca}$

\begin{tabular}{|c|c|c|c|c|c|c|c|c|c|c|c|c|c|c|c|c|c|c|}
\hline 1 & $\mathbf{F}$ & 26 & $8 \cdot 70$ & $2 \cdot 5$ & - & - & $8 \cdot 70$ & $2 \cdot 1$ & - & - & $8 \cdot 70$ & $2 \cdot 5$ & $8 \cdot 48$ & $2 \cdot 5$ & $8 \cdot 70$ & $2 \cdot 6$ & $8 \cdot 66 \pm 0 \cdot 10$ & $2.44 \pm 0.1 \bar{q}$ \\
\hline 2 & $\mathbf{M}$ & 36 & $8 \cdot 70$ & $3 \cdot 4$ & - & - & $9 \cdot 22$ & $4 \cdot 1$ & - & - & 8.80 & $4 \cdot 0$ & 8.98 & $4 \cdot 0$ & $8 \cdot 85$ & $3 \cdot 5$ & $8.91 \div 0.20$ & $3.80 \div 0.32$ \\
\hline 3 & $\mathbf{F}$ & 22 & $9 \cdot 10$ & 3.8 & - & - & $9 \cdot 22$ & $4 \cdot 1$ & - & - & $9 \cdot 48$ & 4.5 & 8.98 & 4.5 & $9 \cdot 18$ & 3.0 & $9 \cdot 19 \pm 0.19$ & $3.98 \pm 0.62$ \\
\hline 4 & $\mathbf{F}$ & 22 & $9 \cdot 42$ & $3 \cdot 2$ & - & - & $9 \cdot 45$ & $3 \cdot 1$ & - & - & $9 \cdot 70$ & $3 \cdot 3$ & $9 \cdot 30$ & $4 \cdot 2$ & 8.92 & $5 \cdot 1$ & $9 \cdot 36 \pm 0.28$ & $3.78 \pm 0.8 \bar{\sigma}$ \\
\hline 5 & $\mathbf{M}$ & 29 & $9 \cdot 45$ & $3 \cdot 8$ & - & 一 & $9 \cdot 55$ & 4.5 & - & - & $9 \cdot 32$ & $4 \cdot 2$ & $8 \cdot 70$ & 3.8 & $9 \cdot 47$ & 4.5 & $9.30 \pm 0.34$ & $4 \cdot 16+0.35$ \\
\hline 6 & $\mathbf{M}$ & 32 & 9.05 & $3 \cdot 3$ & - & - & $9 \cdot 55$ & $3 \cdot 6$ & - & - & 9.00 & $4 \cdot 1$ & $9 \cdot 22$ & $4 \cdot 0$ & $8 \cdot 72$ & $4 \cdot 6$ & $9.11 \pm 0.31$ & $3.92 \pm 0.50$ \\
\hline 7 & $\mathbf{M}$ & 50 & $9 \cdot 62$ & 4.5 & - & - & $9 \cdot 72$ & 4.5 & - & - & $9 \cdot 72$ & 3.9 & $9 \cdot 32$ & 4.6 & - & - & $9 \cdot 60+0.19$ & $4.38+0.35 \mathrm{D}$ \\
\hline 8 & $\mathbf{M}$ & 28 & $9 \cdot 32$ & $4 \cdot 2$ & - & - & $9 \cdot 45$ & $4 \cdot 4$ & - & - & $9 \cdot 32$ & $4 \cdot 3$ & $9 \cdot 22$ & 4.6 & $9 \cdot 32$ & $4 \cdot 0$ & $9.33 \pm 0.08$ & $4.30 \pm 0.22$ \\
\hline 9 & $\mathbf{M}$ & 26 & $9 \cdot 10$ & $4 \cdot 3$ & - & - & $9 \cdot 27$ & $3 \cdot 6$ & - & - & $9 \cdot 65$ & 3.9 & $9 \cdot 15$ & 3.9 & $9 \cdot 15$ & $4 \cdot 5$ & $9.26 \pm 0.22$ & $4.04 \pm 0.36$ \\
\hline 10 & $\mathbf{M}$ & 22 & $9 \cdot 65$ & $2 \cdot 8$ & $9 \cdot 52$ & $3 \cdot 1$ & - & - & $9 \cdot 42$ & $3 \cdot 2$ & 9.62 & $3 \cdot 3$ & 9.52 & 3.8 & 9.25 & 3.6 & $9 \cdot 50 \pm 0.15$ & $3.30 \pm 0.36-$ \\
\hline 11 & $\mathbf{M}$ & 23 & $9 \cdot 22$ & $3 \cdot 6$ & 9.62 & $3 \cdot 2$ & - & - & $9 \cdot 52$ & $4 \cdot 0$ & $9 \cdot 52$ & $4 \cdot 5$ & $9 \cdot 30$ & 5.0 & $9 \cdot 15$ & $4 \cdot 2$ & $9.39 \pm 0.19$ & $4.08 \pm 0.69$ \\
\hline 12 & $\mathbf{M}$ & 26 & $9 \cdot 60$ & $2 \cdot 8$ & $9 \cdot 40$ & 3.6 & - & - & $9 \cdot 30$ & - & $9 \cdot 18$ & - & $8 \cdot 80$ & $3 \cdot 4$ & - & - & $9.26 \pm 0.30$ & $3.27 \pm 0.41$ \\
\hline Mean & - & - & $9 \cdot 24$ & $3 \cdot 52$ & $9 \cdot 51$ & $3 \cdot 30$ & $9 \cdot 35$ & $3 \cdot 78$ & $9 \cdot 41$ & $3 \cdot 60$ & $9 \cdot 33$ & $3 \cdot 86$ & 9.08 & 4.03 & $9 \cdot 07$ & 3.96 & & \\
\hline$\pm \mathrm{SD}$ & - & - & $\pm \mathbf{0 . 3 3}$ & $\pm 0 \cdot 64$ & \pm 0.11 & \pm 0.26 & $\pm 0 \cdot 30$ & \pm 0.79 & $\pm 0 \cdot 11$ & \pm 0.57 & $\pm 0 \cdot 35$ & \pm 0.61 & $\pm \mathbf{0 . 3 0}$ & $\pm 0 \cdot 65$ & $\pm 0 \cdot 26$ & \pm 0.78 & & ते \\
\hline $\mathbf{P}^{3}$ & - & 一 & - & - & - & - & $>0.40$ & $>0.40$ & 一 & - & $>0.50$ & $>0 \cdot 10$ & $>0.20$ & $>0.05$ & $>0.10$ & $>0 \cdot 10$ & & \\
\hline
\end{tabular}

Table I Plasma calcium and phosphorus concentrations in 12 normal subjects during a normal working dip

${ }^{1}$ Fasting specimen.

${ }^{2}$ Concentrations of plasma calcium (Ca) and phosphorus (P) in $\mathrm{mg}$ per $100 \mathrm{ml}$.

${ }^{3}$ Significance of difference of mean at any one time from fasting mean.



Fig. 2 Changes in plasma phosphorus concentration in 12 normal subjects during a normal working day plotted as the difference in $\mathrm{mg}$ per $100 \mathrm{ml}$ from the 0900 hour fasting concentration. The mean difference from the fasting concentration at each time is also plotted. The dietary calcium intake in $\mathrm{mg}$ (black areas) and times taken are also shown. 
concentrations the lowest values obtained, and in three (nos. 1, 10, and 12) the fasting values were the highest values obtained. In only four of the subjects (nos. 5, 6, 10, and 12) were the fasting plasma phosphorus concentrations the lowest values obtained. In each subject the difference, or change in the concentrations of both calcium and phosphorus from the fasting value were also calculated, and these are shown plotted in Figures 1 and 2 respectively together with the mean difference at each of the times studied.

The study was repeated in three subjects (nos. 1, 2, and 6) who fasted from the preceding evening throughout a normal working day. Owing to hunger symptoms the study was stopped in all the subjects at 1700 hours. The full results $\frac{}{\circ}$ are detailed in Table II. The changes in the concentrations of both calcium and phosphorus $\stackrel{0}{-}$ from the 0900 hour value are shown in Figure 3. In these subjects there were virtually no fluctu-음 ations in plasma calcium concentration, although? fluctuations did occur in plasma phosphorus $\mathbb{2}$ concentration. In view of the small number of sub-» jects these values were not compared statistically.

\begin{tabular}{|c|c|c|c|c|c|c|c|c|c|c|}
\hline \multirow[t]{3}{*}{ Subject } & \multicolumn{8}{|c|}{ Time (hours) } & \multicolumn{2}{|c|}{ Mean } \\
\hline & \multicolumn{2}{|l|}{0900} & \multicolumn{2}{|l|}{1200} & \multicolumn{2}{|l|}{1500} & \multicolumn{2}{|l|}{1700} & \multirow[t]{2}{*}{$\mathrm{Ca}$} & \multirow[t]{2}{*}{$\boldsymbol{P}$} \\
\hline & $C a^{1}$ & $P^{1}$ & $\mathrm{Ca}$ & $\boldsymbol{P}$ & $\mathrm{Ca}$ & $\boldsymbol{P}$ & $\mathrm{Ca}$ & $\boldsymbol{P}$ & & \\
\hline $\begin{array}{l}1 \\
2 \\
6\end{array}$ & $\begin{array}{l}8 \cdot 72 \\
9 \cdot 65 \\
9 \cdot 22\end{array}$ & $\begin{array}{l}2 \cdot 5 \\
4 \cdot 8 \\
3 \cdot 7\end{array}$ & $\begin{array}{l}8 \cdot 62 \\
9 \cdot 65 \\
9 \cdot 12\end{array}$ & $\begin{array}{l}2 \cdot 7 \\
4 \cdot 1 \\
3 \cdot 5\end{array}$ & $\begin{array}{l}8 \cdot 85 \\
9 \cdot 80 \\
9 \cdot 22\end{array}$ & $\begin{array}{l}2 \cdot 6 \\
4 \cdot 5 \\
3 \cdot 3\end{array}$ & $\begin{array}{l}8 \cdot 82 \\
9 \cdot 80 \\
9 \cdot 22\end{array}$ & $\begin{array}{l}2 \cdot 7 \\
5 \cdot 0 \\
4 \cdot 1\end{array}$ & $\begin{array}{l}8 \cdot 75 \\
9 \cdot 73 \\
9 \cdot 20\end{array}$ & $\begin{array}{l}2.63 \\
4.60 \\
3.65\end{array}$ \\
\hline Mean & $9 \cdot 20$ & $3 \cdot 67$ & $9 \cdot 13$ & $3 \cdot 43$ & $9 \cdot 29$ & $3 \cdot 47$ & $9 \cdot 28$ & 3.93 & & \\
\hline
\end{tabular}

Table II Plasma calcium and phosphorus concentrations in three normal subjects while fasting during a normal working day

${ }^{1}$ Plasma concentrations of calcium (Ca) and phosphorus (P) in $\mathrm{mg}$ per $100 \mathrm{ml}$.

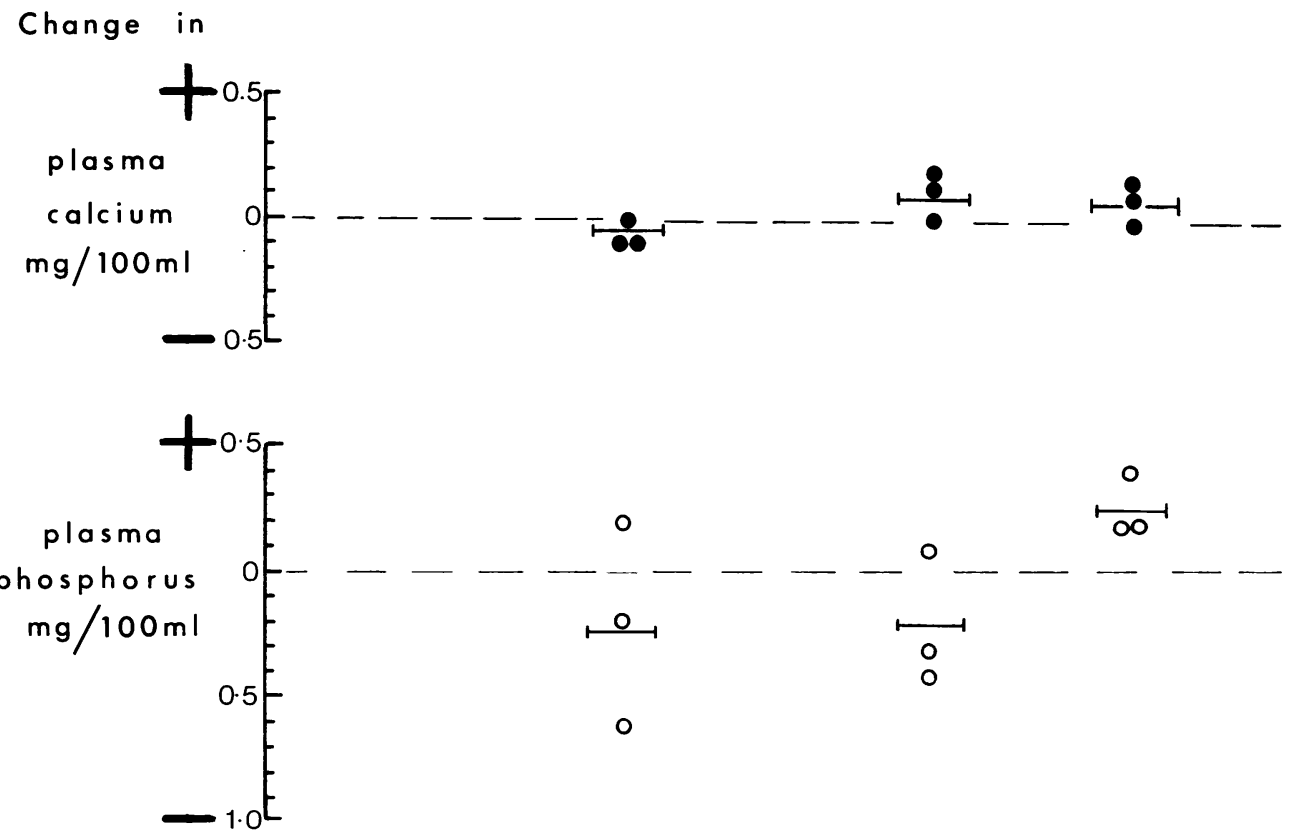

Fasting

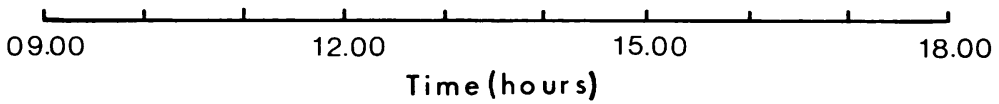

Fig. 3 Changes in plasma calcium and phosphorus concentrations in three normal subjects while fasting during a normal working day. The changes are plotted as the difference in $\mathrm{mg}$ per $100 \mathrm{ml}$ from 0900 hour concentrations. 
Discussion

In all the normal subjects studied some degree of fluctuation occurred in both the plasma calcium and phosphorus concentrations during a normal working day. At no time during the day of study did the mean values for all the subjects differ significantly from the mean fasting values for either the plasma calcium or phosphorus concentration. In the individual subjects the fluctuations in plasma calcium concentration from the fasting value ranged from a maximum of $+0.55 \mathrm{mg}$ per $100 \mathrm{ml}(1500$ hours in subject 9) to $-0.80 \mathrm{mg}$ per $100 \mathrm{ml}$ (1800 hours in subject 12). These fluctuations were presumably due to the oral intake of calcium in the diet as in the three subjects who were studied while fasting during a normal working day the fluctuations in plasma calcium concentration relative to the 0900 hour concentration ranged from $+0 \cdot 15$ to $-0.10 \mathrm{mg}$ per $100 \mathrm{ml}$. The individual fluctuations from the fasting value in plasma phosphorus concentration, during a normal working day, ranged from $+1.9 \mathrm{mg}$ per $100 \mathrm{ml}$ (subject 4 at 1800 hours) to $-0.8 \mathrm{mg}$ per $100 \mathrm{ml}$ (subject 3 at 1800 hours). These fluctuations were not as markedly reduced by fasting as were the fluctuations in calcium concentration. The fluctuations in the plasma phosphorus concentration that did occur during both the normal and the fasting days were relatively large when compared with the total plasma concentration. The results suggest that the time of day at which blood samples are collected for the estimation of total plasma calcium concentration does not cause an important difference in the estimated value when compared with the fasting concentration. As dietary calcium intake caused fluctuations in the total plasma calcium concentration in any one individual subject, fasting samples should always be collected when the therapeutic effects of different regimens are being studied.

The findings reported here are in accordance with some but not all of the previous reports in the literature. Greenberg and Gunther (1930, 1932) reported that there were no circadian changes in plasma calcium concentration in fasting subjects. Watchorn (1929) found no appreciable variation in plasma calcium concentration throughout a day, and they concluded that it was 'not necessary to ensure that the subject is fasting when blood is taken'. Farquharson and Tibbetts (1931), in a study of two healthy adults during ordinary work and on a normal diet, reported that the plasma calcium concentration was constant in one, while in the other the values varied between 9.4 and $10.4 \mathrm{mg}$ per $100 \mathrm{ml}$ during the day. Nicolaysen (1932) reported fluctuations of 2 to $3 \mathrm{mg}$ per $100 \mathrm{ml}$ in fasting subjects during a 24-hour period. Philpot (1958), in one of his subjects, reported fluctuations in the plasma calcium concentration between $10 \cdot 1$ and $11.0 \mathrm{mg}$ pe $\frac{\rho}{5}$. $100 \mathrm{ml}$ during a normal day with a variation ofo 9.7 to $10.0 \mathrm{mg}$ per $100 \mathrm{ml}$ during a day of fasting Chaptal et al (1962) in one normal subject, op a normal diet, reported considerable fluctua: tions in the plasma calcium concentration ovef? a 24-hour period. In 12 normal subjects Wesso (1964) reported that there was a 'poorly define but statistically significant cycle' in the plasm\& calcium concentration. Carruthers et al $(1964) \mathbb{R}$ in a study of circadian variations in five normał individuals under standardized conditions of calcium intake, reported that 'a remarkably constant plasma calcium level was observed in all subjects'. In four normal subjects Hodgkinsor? and Heaton (1965) reported that there was ne consistent change in serum calcium or inorganidu phosphorus concentrations during fasting. Briscoee and Ragan (1966) in a study of seven patient over three days reported that there was a 'slight but consistent' diurnal variation in serum calo cium concentration with lower values in the morning. In the subjects reported here, although fluctuations did occur in plasma calcium concen trations, the mean values did not differ signi ficantly from the fasting concentration during the study period.

Circadian variations in plasma phosphorus concentration have been well established with low values in the morning followed by an increase in the afternoon and evening (Wesson, 1964 Carruthers et al, 1964; Mills, 1966). The results in the three fasting normal subjects (Fig. 30 are in accordance with these earlier reports.

Plasma calcium concentration in man is regulated in a precise manner primarily by parathyroid hormone and calcitonin probably? under a feedback control mechanism (Copp? 1969), although the physiological significances of calcitonin in normal homeostasis is not aह present well established (Copp, 1969). It hasbeen reported that the absolute concentration at which the plasma calcium concentration is maintained is related to total dietary calciumb intake, with significantly lower values in normaP subjects on a low calcium diet compared with ao normal calcium diet (MacFadyen, Nordin, Smith, Wayne, and Rae, 1965). Recently however, $\mathrm{N}$ Phang, Berman, Finerman, Neer, Rosenberg, $N$ and Hahn (1969) have reported results in disagreement with these observations, in that they $\sigma$ found no significant difference in serum calciunt concentrations in normal subjects while takinge normal and either high or low calcium intakes. $\$$ The precise control mechanisms of total plasma calcium concentration and the 'rigidity' of the -0 ' control shown in the study reported here requires $\vec{D}$ further investigation. The recent hypothesis of Nordin and Peacock (1969) that this control is $\varrho$ undertaken through the action of parathyroid hormone on the kidneys is of particular interest 8 in this respect. 
I am indebted to Dr G. K.McGowan, in whose department this work was performed, for helpful advice and criticism, and to my colleagues, who willingly acted as the subjects for these studies.

\section{References}

Briscoe, A. M., and Ragan, C. (1966). Diurnal variations in calcium and magnesium excretion in man. Metabolism, $15,1002-1010$.

Carruthers, B. M., Copp, D. H., and McIntosh, H. W. (1964). Diurnal variation in urinary excretion of calcium and phosphate and its relation to blood levels. J. Lab. clin. Med., 63, 959-968.

Chaptal, J., Jean, R., Guillamot, R., and Morel, G. (1962). Etude des variations nycthémérales dans le sang et les urines de quelques constantes biologiques, notamment du phosphore et du calcium. Enregistrement 'in vivo' et en continu pendant vingt-quatre heures de la concentration urinaire du phosphore. Résultats obtenus chez un sujet normal, et chez un enfant hypoparathyroidien traité par AT10 et vitamine D. Ann. Pédiat., 38, 90-96.

Copp, D. H. (1969). Endocrine control of calcium homeostasis. J. Endocr., 43, 137-161.

Dent, C. E. (1962). Some problems of hyperparathyroidism. Brit. med. J., 2, 1419-1425 and 1495-1500.

Farquharson, R. F., and Tibbetts, D. M. (1931). Studies of calcium and p'osphorus metabolism. XVIII On temporary fluctuations in the level of calcium and inorganic phosphorus in blood serum of normal individuals. J. clin. Invest., 10, 271-286.

Fiske, C. H., and Subbarow, Y. (1925). The colorimetric determination of phosphorus. J. biol. Chem., 66, 375-400.
Greenberg, D. M., and Gunther, L. (1930). The diffusible calcium of the blood stream in allergic diseases. Arch. intern. Med., 46, 72-74.

Greenberg, D. M., and Gunther, L. (1932). Diffusible calcium of the blood stream. III Influence of agents which affect blood calcium distribution and inorganic phosphate of serum. Arch. intern. Med., 50, 855-875.

Hodgkinson, A., and Heaton, F. W. (1955). The effect of food $\bar{F}$ ingestion on the urinary excretion of calcium and magnesium. Clin. chim. Acta, 11, 354-362.

MacFadyen, I. J., Nordin, B. E. C., Smith, D. A., Wayne, D. J., 음 and Rae, S. L. (1965). Effect of variation in dietary cal- $\bar{\omega}$ cium on plasma concentration and urinary excretion $\vec{D}$ of calcium. Brit. med. J., 1, 161-164.



Nicolaysen, R. (1932). Schwankungen des Blutkalkspiegels $\overrightarrow{-}$ beim fastenden Menschen. Biochem. Z., 248, 275-277.

Nordin, B. E. C., and Peácock, M. (1969). Role of kidney in regulation of plasma-calcium. Lancet, 2, 1280-1283.

Phang, J. M., Berman, M., Finerman, G. A., Neer, R. M. Rosenberg, L. E., and Hahn, T. J. (1969). Dietary perturbation of calcium metabolism in normal man: compartmental analysis. J. clin. Invest., 48, 67-77.

Phillips, R. A., van Slyke, D. D., Dole, V. P., Emerson, K., Jr., Hamilton, P. B., and Archibald, R. M. (1945). Copper. Sulphate Method for Measuring Specific Gravities of Whole Vᄀ Blood and Plasma. Josiah Macey, New York.

Philpot, G. R. (1958). Calcium Metabolism in Humans. Ph.D. $ᄋ$ Thesis, University of London.

Watchorn, E. (1929). Thesis, Cambridge. Quoted in Watchorn and McCance (1932).

Watchorn, E., and McCance, R. A. (1932). Inorganic constituents $\overparen{\Phi}$ of cerebrospinal fluid, II: The ultrafiltration of calcium $\mathbb{D}$ and magnesium from human sera. Biochem. J., 26, 54-64. 3

Wesson, L. G., Jr. (1964). Electrolyte excretion in relation to diurnal cycles of renal function. Medicine (Baltimore), 43, 547-592.

Wills, M. R., and Gray, B. C. (1964). Micro-method for the $\vec{\theta}$ estimation of calcium by Autoanalyzer. J. clin. Path., $\bigcirc$ 17, 687-689. 